\title{
Tomographic imaging of fragmented cortical bone heteroimplant and methylmethacrylate in segmental bone defect of rabbit tibia ${ }^{1}$
}

\author{
Silvio Henrique de Freitas ${ }^{\mathrm{I}}$, Renata Gebara Sampaio Dória ${ }^{\mathrm{II}}$, Fábio de Souza Mendonça ${ }^{\mathrm{III}}$, Marcelo Diniz dos Santos ${ }^{\mathrm{III}}$, Jair \\ Rodini Engrácia Filho ${ }^{\text {IV }}$, Atanásio Serafim Vidanev , Alessandro Tadeu Corrêa Marques ${ }^{\text {VI }}$, Carlos Eduardo Ambrósio ${ }^{\text {VII }}$
}

DOI: http://dx.doi.org/10.1590/S0102-86502014001900005

${ }^{I} \mathrm{PhD}$, Professor, Postgraduate Program in Animal Bioscience (PPBA), Faculty of Veterinary Medicine (FMV), University of Cuiaba (UNIC), CuiabaMT, Brazil and Postdoctoral Fellowship, Department of Veterinary Medicine (DMV), Faculty of Animal Sciences and Food Engineering (FZEA), University of Sao Paulo (USP), Pirassununga-SP, Brazil. Technical procedures, critical revision, approved the final manuscript.

IPhD, Professor, PPBA, FMV, UNIC, Cuiaba-MT, Brazil. Acquisition of data, supervised all phases of the study.

"PhD, Professor, PPBA, FMV, UNIC, Cuiaba-MT, Brazil. Technical procedures.

${ }^{\text {IV }} \mathrm{PhD}$, Researcher, Department of Pathology, Faculty of Agriculture and Veterinary Sciences, Sao Paulo State University Júlio de Mesquita Filho (UNESP). Jaboticabal-SP, Brazil. Analysis of data, manuscript preparation.

${ }^{v}$ Master, Fellow PhD degree, Postgraduate in Anatomy of Domestic and Wild Animals, Department of Surgery, Faculty of Veterinary Medicine and Animal Science, USP, Sao Paulo-SP, Brazil. Interpretation of data, manuscript preparation.

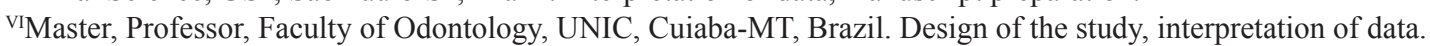

${ }^{\mathrm{VII}} \mathrm{PhD}$, Associate Professor, DMV, FZEA, USP, Pirassununga-SP, Brazil. Interpretation of data, manuscript writing, critical revision.

\begin{abstract}
PURPOSE: To evaluate the performance of composites consisting of fragmented cortical bone heteroimplant in association with methylmethacrylate preserved in 98\% glycerin, in segmental bone defect of rabbit tibia medial metaphysis.

METHODS: In this study were used twelve adult New Zealand rabbits, divided into three groups of four animals each: G30 (30 days), G60 (60 days) and G90 (90 days). The bone defects previously created in the tibia were filled with composites and both were evaluated by cone-beam computed tomography, immediately after surgery and after 30, 60, and 90 days.

RESULTS: The composites fulfilled and remained in the sites of bone defects in all cases and were not registered signals of infection, migration or rejection.
\end{abstract}

CONCLUSIONS: The implanted composites promoted the bone defects repair without signals of infection and/or rejection. The composites are one more option for bone defects repair.

Key words: Biocompatible Materials. Tomography. Tibia. Rabbits. 


\section{Introduction}

The trauma leading to bone fractures, especially the comminuted fractures, play a key role in both clinical and surgical veterinary medicine routine, similar in human. Moreover, diseases such as osteomyelitis, non-unions, bone tumors, and others who require reconstructive orthopedics replacement of bone tissue are common ${ }^{1-3}$. The alternative treatment for bone defects is the spongious autograft, which involves the removal of spongious bone tissue from the patient, biologically compatible and accelerates bone repair. Nevertheless, the inconvenience of this procedure is that occurs in two stages, increasing patient morbidity by damaging normal structures, the pain, and prolongs the anesthetic and surgical period, and did not provides enough bone volume to repair large bone defects ${ }^{3,4}$.

To prevent problems inherent to autograft, the current methods to treat fractures with large bone defects consist on biological or synthetic biomaterials, which are biocompatible and able to interact with the living system ${ }^{4,5}$. The bone tissue derived from the same species (aloimplats) or from different species (heteroimplants) are biological biomaterials that have been used with satisfactory results to repair bone defects $\mathrm{s}^{3,6,7}$.

Furthermore, the heteroimplants have osteoinductive properties, which occur by bone tissue formation from osteoprogenitor cells, derived from primitive mesenchymal cells under the influence of one or more inductive factors from bone matrix. Moreover, promotes the bone growth by affixing the subjacent bone tissue in the presence of bone or undifferentiated mesenchymal cells, featuring the osteoconductive properties. In addition, they must be biocompatible, non-carcinogenic, nontoxic, non-antigenic and not stimulate inflammatory processes or favor the infection ${ }^{4,8}$.

The orthopedic disorders in bone defects may also be efficiently fulfilled by synthetic biomaterials, such as calcium phosphate cement, hydroxyapatite, lactic glycolic copolymer, methylmethacrylate, and others ${ }^{9-11,20}$. The methylmethacrylate has bioinert and biotolerable properties, can be molded to obtain a more adequate form, therefore is currently widely used in orthopedic surgical procedures to repair large bone defects ${ }^{2,12,18}$.

A new approach for large bone defects repair would be a composites consisting of biological biomaterials (heteroimplants) and synthetic biomaterials (methylmethacrylate) with osteogenic, osteoinductive and osteoconductive properties, not favoring bacterial colonization or infection, which would provide mechanical stability, easy acquisition cost, did not require a specialized environment for their preservation, and completely fulfill the bone defect, eliminating thereby the problems inherent to autograft $3,13,19$.

Besides radiographic examination, the biomaterials behavior can also be assessed by computed tomography (CT), which allows a visualization of all the three-dimensional layered structures, in particular the mineralized tissues. The imaging method allows a playback of a tissue cut section in any one of the three spatial planes. While the conventional radiographic technique which projects in a single plan all structures penetrated by x-radiation, the CT technique allows the evidence of depth structural relationships, showing images of tissues in serial sections (slices) in high definition. It allows evaluating, defining, limiting and quantifying the bone tissue reactions ${ }^{4,14-16}$.

Therefore, is proposed in this study, the evaluation of cortical bone fragmented heteroimplant (HOCF) behavior, associated with methylmethacrylate in segmental bone defects in rabbit tibiae through cone beam computed tomography.

\section{Methods}

This study was approved by the University of CuiabaINIC Ethical Committee in animal research (2010-049), according to Resolution 196/96 of the National Health Council.

Twelve adult New Zealand rabbits, weighing an average of about $3 \mathrm{~kg}$, divided into three groups of four animals each were used as recipients: G30 (30 days postoperative), G60 (60 days) and G90 (90 days).

The cortical bone heteroimplant (HOC) was collected aseptically from canine tibial diaphysis, clinically healthy, with a history of traumatic death. The smooth tissues adjacent to tibia, epiphysis and bone marrow were removed, then, the diaphysis was collected, washed with $0.9 \%$ saline solution $\left(0.9 \%\right.$ saline solution ${ }^{\circledR}$, JP Pharmaceutical Industry S/A, Brazil ) and conditioned in 98\% glycerin (glycerin ${ }^{\circledR}$, VIC Pharma Industry and Commerce Ltda, Brazil), for a period not less than 30 days, at room temperature. For its use, the cortical bone hetroimplant (HOC) was hydrated in $0.9 \%$ saline solution for 10 minutes, divided into small particles approximately $2 \mathrm{~mm}$ using the orthopedic nibbler, and finally dehydrated at room temperature. The cortical bone fragmented heteroimplant (HOCF) was mixed with methylmethacrylate polymer powder (1:1) and the liquid monomer (Vipi Flash ${ }^{\circledR}$, Vipi Industries, Trade, Import Export, Brazil) was added until the pasty consistency was reached. The implant was then molded to the template of $6 \mathrm{~mm}$ diameter and $2 \mathrm{~mm}$ thickness. The generated 
composites were conditioned in $98 \%$ glycerin at room temperature for at least 30 days.

Preoperatively the trichotomy of medial proximal region of the left tibia was performed, and the animals were anesthetized with combination of acepromazine $(0.1 \mathrm{mg} / \mathrm{kg})\left(0.2 \%\right.$ Acepran $^{\circledR}$, Univet S/A, Brazil) and tiletamine / zolazepam (20mg/kg) (50 Zoletil $^{\circledR}$, Virbac's Brazil Industry and Commerce Ltda, Brazil), via intramuscular, followed by local infiltration anesthetic using 0.4 $\mathrm{mL}$ of lidocaine $2.0 \%$ (Lidovet $^{\circledR}$, Bravet, Brazil).

In dorsal decubitus under padded metal gutter, the antisepsis was performed using povidone-iodine (Topic Riodeine ${ }^{\circledR}$, Pharmaceutical Riochemistry Ltda, Brazil), and then was made an incision on the skin and the proximal medial cortex of the left tibia was exposed. Using a trephine drill ( Trephine Drill ${ }^{\circledR}$, Dental Aragon, Brazil) attached to an autoclavable low speed electric drill (Autoclavable Electric Drill $^{\circledR}$, Caomedica, Brazil), was created a bone defect in this region, by removing a corticoperiosteal segment (6mm diameter). The bone defect was fulfilled with composite previously hydrated in $0,9 \%$ of saline solution, the periosteum and the subcutis were approached with 3.0 polyglycolic acid (Medcryl ${ }^{\circledR}$, Med Goldman, Manaus, Brazil), and the skin was positioned with 3.0 polyamide yarn $\left(\mathrm{Nylon}^{\circledR}\right.$, Brasmedica, Brazil). Five consecutive applications of enrofloxacin $(10 \mathrm{mg} / \mathrm{kg})\left(2.5 \%\right.$ Flotril $^{\circledR}$, Intervet Schering-Plough, Brazil) were performed subcutaneously every 24 hours; threeconsecutiveapplications of tramadolhydrochloride $(4 \mathrm{mg}$ / kg) (Tramadol hydrochloride ${ }^{\circledR}$, Hipolabor, Brazil) subcutaneously every 8 hours, and two daily dressings with rifampicin (Rifocina spray, Pharmaceutical Laboratory of Pernambuco, Brazil) until the tenth day, when the wound stitches were removed. Postoperatively, the animals were housed individually in cages, climate-controlled environment, fed with commercial diet (Feed Labina ${ }^{\circledR}$, Purina, Brazil) and water ad libitum.

After each postoperative estimated time: 30, 60 and 90 days, the animals were euthanized using the anesthetic protocol previously described, followed by cardio-respiratory arrest with propofol (Propovan ${ }^{\circledR}$, Cristalia, Brazil) and 10\% of potassium chloride (Potassium Chloride $10 \%{ }^{\circledR}$, Alexistar, Brazil) intravenously. The implanted tibias with the composites were evaluated by cone beam computed tomography - Cone beam $(60 \mathrm{kV}-2.5 \mathrm{~mA}-10.8 \mathrm{~s}$,
KODAK 9000 3D model, Carestream Health, France).

\section{Results}

All animals supported the operated limbs immediately in the postoperative period, showing that the tibia structures were not compromised, and the surgical wounds healed in an average period of 15 days without signs of infection and/or reaction that would suggest rejection.

In the immediate postoperative period, all implanted tibias

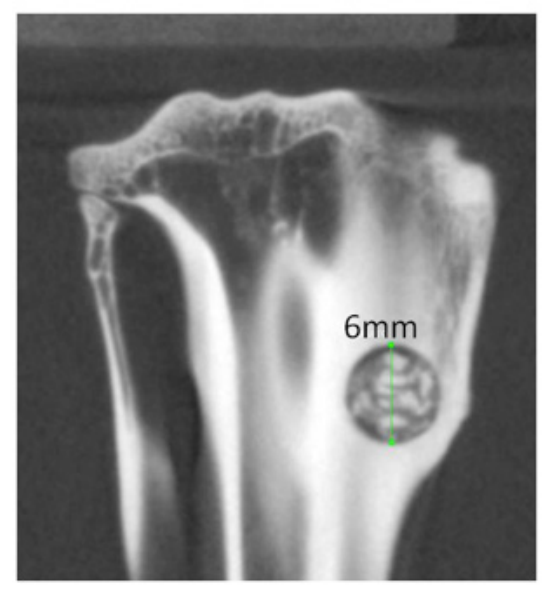

FIGURE 1 - CT scan of the proximal region of rabbit tibia in the immediate postoperative period. The composite in the recipient implanted site, showing radiolucent areas (methylmethacrylate) and radiopaque (HOCF). Sagittal section, $0.8 \mathrm{~mm}$ thickness.

were evaluated by cone beam computed tomography, to confer the real position of implants in the receptors patients (Figure1).

The computed tomographic evaluations, at the coronal and axial sections in the rabbits tibias from each group G30 (Figures 2A and B), G60 (Figures 2C and D) and G90 (Figure 2E and F), revealed that all the composites remained in the implanted sites, no sign of proliferation or bone lysis, or reactions was reported.

Moreover, the CT scan also revealed heterogeneous densities of all composites, consisting of radiolucent areas, corresponding to methylmethacrylate, and radiopaque areas, corresponding to $\mathrm{HOCF}$, during all the evaluation period (Figures 2B, 2D and 2F).

The radiopacity between composite interfaces increased in the animals of G60 (Figure 2C) and G90 groups (Figure 2E), 

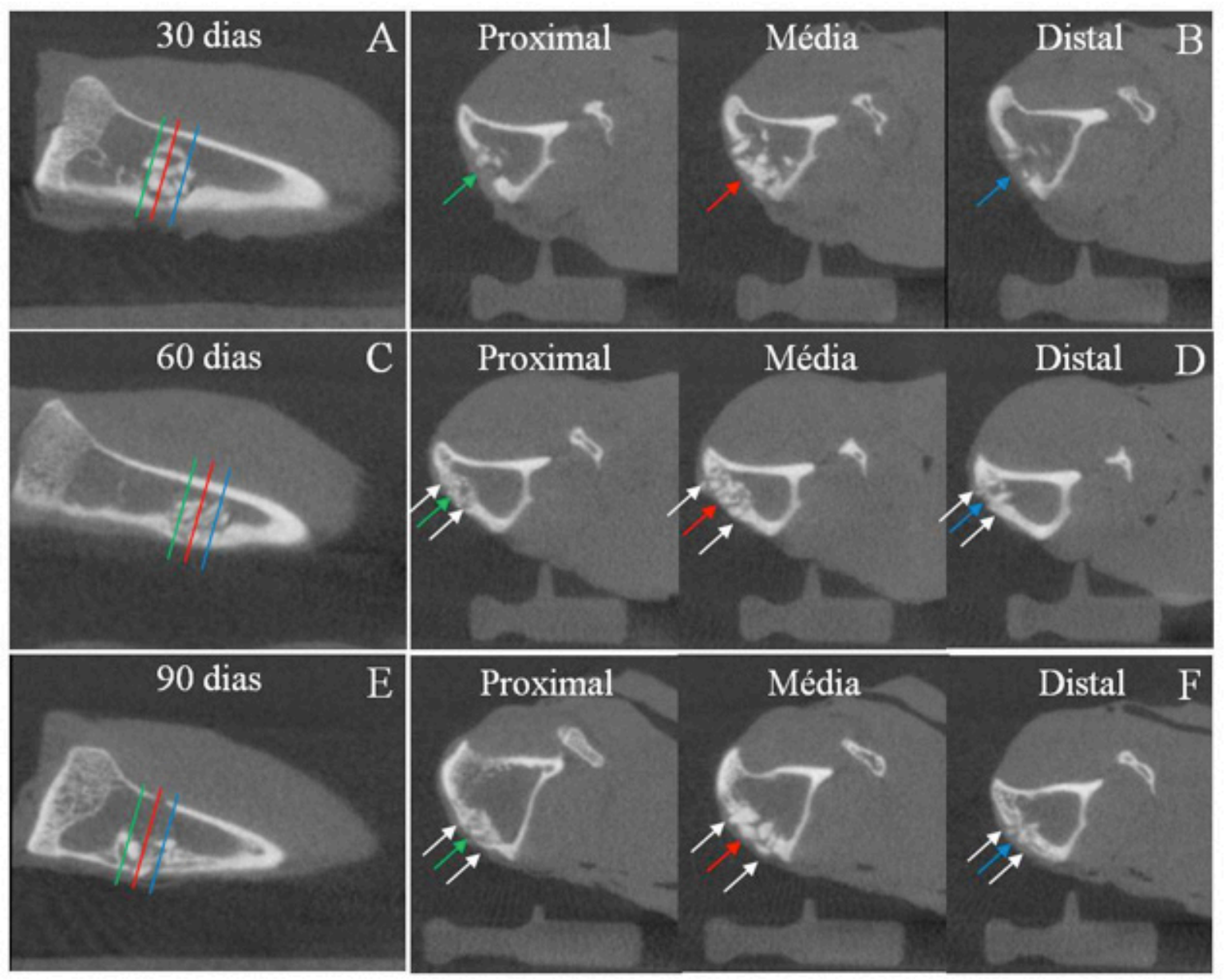

FIGURE 2 - CT scan of the proximal region of rabbit tibia at 30,60 and 90 days. A, C and E: The composite in the recipient implanted site - green, red and blue lines (coronal section in anteroposterior position). B, D and F: The absence of reactions in the following portions: proximal - green arrow, medium - red and distal arrow - blue arrow (axial section). C and E: The high radiopacity in the composite - recipient interfaces (white arrows). Sections: $1.1 \mathrm{~mm}$ interval and 0,076 mm thickness.

due to increased density characterized by apposition of bone tissue and composite incorporation.

\section{Discussion}

All the materials and tools used directly for composite preparation were sterilized. Furthermore, the composites were stored at $98 \%$ glycerin over 30 days, period which, according to Vilela et $a l .{ }^{17}$ and Freitas et $a l .{ }^{2}$, is long enough for the bactericidal properties of this preservation medium destroy totally the all bacteria present in the implants. If these microorganisms colonize the surgical wound, they would occur the bone lysis and therefore, instability and migration of the composites in the site of transplantation

All animals supported the operated limbs immediately in the postoperative period, showing that the tibia structures were not compromised with osteotomy. Moreover, the analgesic effect reduced the pain and stress and also provided more comfort to the patient, and it may have contributed to the early use of the limb $b^{3}$.
All animals (100\%) had wounds healed within 15 days, exempt infection signal or tissue reaction, showing that the preoperatively and postoperatively care (antisepsis, asepsis and antibiotic therapy) were efficient ${ }^{15}$.

When HOCF in association with methylmethacrylate (pasty consistency) are applied directly in the receptor bone defect, it could cause thermal necrosis and lysis of the bone tissue due to the exothermic reaction produced by the polymerization of methylmethacrylate. However, this was not observed in this study because before implantation, the composites were completely polymerized, therefore no exothermic reaction occurred at the time of its accommodation in the implantation site. According to Freitas et al. ${ }^{2}$ and Moreira et al. ${ }^{4}$, it was decisive for its full incorporation into the bone defect.

The composite incorporation and engraftment to the all recipient bone defect, is indicative of rejection absence and existence of osteoinductive properties, characterized by 
angiogenesis and fibroblast invasion involved with the bone tissue deposition, which also characterizes the osteoconduction ${ }^{7}$.

The cone beam computed tomography allowed monitoring and satisfactory demonstration the composite behavior in the rabbit tibias in different evaluation phases. In this study, was possible to observe the bone tissue deposition and remodeling, since this technique also allows high resolution 3D tissue imaging. Therefore, in human odontology the cone beam CT is widely used to assess mineralized bone tissue and monitoring bone remodeling post-graft ${ }^{4,15,16}$

The CT scans of orthogonal and axial sections of rabbit tibia, in all groups G30 (Figures 2A and B), G60 (Figures 2C and D) and $\mathrm{G} 90$ (Figures $2 \mathrm{E}$ and $\mathrm{F}$ ) revealed that the composite remained in the implantation site and were reported heterogeneous density of all composites consisting of radiolucent areas, corresponding to methylmethacrylate, and radiopaque areas, corresponding to $\mathrm{HOCF}$, during all the evaluation period (Figures 2B, 2D and $2 \mathrm{~F})$. The radiopacity between composite interfaces increased in the animals of G60 (Figure 2C) and G90 groups (Figure $2 \mathrm{E}$ ), characterized by apposition of bone tissue and composite incorporation. According to Moreira et al. ${ }^{4}$ this findings occur due to composite osteoinductive and osteoconductive properties.

\section{Conclusions}

The composite of cortical bone heteroimplant fragmented (HOCF) and methylmethacrylate was successfully engrafted and promoted the repair of bone defects without signs of infection and/or rejection. Is biologically compatible, therefore, is effective alternative for bone substitute in bone defects healing.

\section{References}

1. Louis PJ. Bone Grafting the Mandible. Oral Maxillofacial Surg Clin North Am. 2011 May;23(2):209-27. doi: 10.1016/j. coms.2011.01.002.

2. Freitas SH, Dória RGS, Mendonça FS, Camargo LM, Presser CI, Santos MD, Shimano AC, Ambrósio CE. Avaliação morfológica e por imagem radiográfica da matriz óssea mineralizada heteróloga fragmentada e metilmetacrilato, preservados em glicerina para reparação de falhas ósseas em tíbias de coelhos. Pesq Vet Bras. 2013 Jun;33(3):765-70. doi: 10.1590/S0100-736X2013000600013.

3. Moreira R, Dória RGS, Camargo LM, Santos MD, Minto BW, De Nardi AB, Ambrósio CE, Freitas SH. Aspecto radiológico e macroscópico de matriz óssea mineralizada heteróloga e polimetilmetacrilato autoclavado em falha óssea de tíbia de coelhos. Pesq Vet Bras. 2014 Feb;34(2):173-8. doi: 10.1590/S0100736X2014000200013.

4. Freitas SH, Dória EGS, Mendonça FS, Santos MD, Moreira R, Simões RS, Camargo LM, Marques ATCM, Simões MJ. Tomografia computadorizada da matriz óssea mineralizada heteróloga fragmentada e metilmetacrilato na reparação de falhas ósseas. Arq Bras Med Vet Zootec. 2012 Dec;64 (6):1547-54. doi: 10.1590/ S0102-09352012000600021.

5. Ziyad S, Haidar RC, Tabrizian HM. Delivery of recombinant bone morphogenetic proteins for bone regeneration and repair Part B: delivery systems for BMPs in orthopaedic and craniofacial tissue engineering. Biotechnol Lett. 2009 Dec;31(12):1825-35. doi: 10.1007/s10529-009-0100-8.

6. Lane JM, Sandhu HS. Current approaches to experimental bone grafting. Orthop Clin North Am. 1987;18(2):213-25. PMID: 3550572.

7. PinheiroI FAL, Mourão CFAB, Diniz VS, Silva PC, Meirelles L, Santos Junior E, Schanaider A. In-vivo bone response to titanium screw implants anodized in sodium sulfate. Acta Cir Bras. 2014 Apr;29(6):376-82. doi: 10.1590/S0102-86502014000600005.

8. Shafiei Z, Bigham AS, Dehghani SN, Torabi Nezhad S. Fresh cortical autograft versus fresh cortical allograft effects on experimental bone healing in rabbits: radiological, Histopathological and Biomechanical evaluation. Cell Tissue Bank. 2009 Feb;10(1):19-26. doi: 10.1007/s10561-008-9105-0.

9. Silva MLA, Crawford A, Mundy JM, Correlo VM, Sol P, Bhattacharya M, Hatton P V, Reis RL, Neves NM. Chitosan/ polyester-based scaffolds for cartilage tissue engineering: assessment of extracellular matrix formation. Acta Biomater. 2010 Mar;6(3):1149-57. doi: 10.1016/j.actbio.2009.09.006.

10. De Marval CA, Alves GES, Las Casas EB, Costa CG, Saffar JME, Lago LA, Carvalho WTV, Leal BB, Faleiros RR. Análise biomecânica ex vivo de um modelo de haste intramedular de polipropileno para osteossíntese em úmeros de bezerros. Arq Bras Med Vet Zootec. 2011 Abr;63(2):273-8. doi: 10.1590/S010209352011000200001.

11. Spadeto Junior O, Rodrigues LB, Carvalho WTV, Moreira DO, De Marval CA, Costa CG, Alves GES, Las Casas EB, Faleiros RR. Sistemas osso-implante ex vivo utilizando haste intramedular polimérica para imobilização de fraturas femorais em bovinos jovens, Cienc Rural. 2011 Feb;41(2);301-6. doi: org/10.1590/ S0103-84782011000200020.

12. Bauer TW. Bone graft substitutes. Skeletal Radiol. 2007 Oct;36(12):1105-7. doi: 10.1007/s00256-007-0377-4.

13. Khan SN, Tomin E, Lane JM. Clinical applications of bone graft substitutes. Orthop Clin North Am. 2000 Jul;31(3):389-98. PMID: 10882465.

14. Misch KA, Yi ES, Sarment DP. Accuracy of cone beam computed tomography for periodontal defect measurements. J Periodontol. 2006 Jul;77(7):1261-6. doi: 10.1902/jop.2006.050367.

15. Marca C, Paul M. H. Dummer PMH, Bryant S, Vier-Pelisser FV, Só MVR, Fontanella V, Dutra VD, Figueiredo JAP. Three-rooted premolar analyzed by high-resolution and cone beam CT. Clin Oral Invest. 2013 Jul;17(6):1535-40. doi: 10.1007/s00784-012-0839-5.

16. Roza MR, Silva LAF, Januário AL, Barriviera M, Oliveira ACA, Fioravanti MCS. Tomografia computadorizada de feixe cônico na odontologia veterinária: descrição e padronização da técnica. Pesq Vet Bras. 2009 Aug;29(8):617-24. doi: 10.1590/S0100736X2009000800004.

17. Vilela LM, Del Carlo RJ, Oliveira RC, Rodrigues MCD, Monteiro BS, Reis AM, Machado DPD. Propriedades mecânicas de meniscos frescos de coelhos e preservados em glicerina 98\%. Cienc Rural. 2010 Jan;40(5):1114-20. doi: 10.1590/S0103-84782010000500018.

18. Alves EGL, Rezende CMF, Oliveira HP, Borges NF, Mantovani PF, Rosado IR. Emprego experimental da placa de compósito polihidroxibutirado/hidroxiapatita na fixação femoral em gatos. Arq Bras Med Vet Zootec. 2010 Oct;62(5):1128-34. doi 10.1590/S010209352010000500015.

19. Petite H, Viateau V, Bensaïd W, Meunier A, Pollak C, Bourguignon 
Freitas SH et al.

M, Oudina K, Sedel L, Guillemin G. Tissue-engineered bone regeneration. Nat Biotechnol. 2000 Sep;18(9):959-63. doi:10.1038/79449.

20. Suominen EA, Aho AJ, Juhanoja J, Yli-Urpo A. Hydroxyapatiteglass composite as a bone substitute in large metaphyseal cavities in rabbits. Int Orthop. 1995;19(3):167-73. PMID: 7558493.

\section{Correspondence:}

Silvio Henrique de Freitas

Rua Siqueira Campos, 4380/casa 530

13631-018 Pirassununga - SP Brasil

Tel.: (55 19)99879-5297

shfreitas@terra.com.br

Received: Aug 18, 2014

Review: Oct 17, 2014

Accepted: Nov 20, 2014

Conflict of interest: none

Financial source: Faculty of Veterinary Medicine, UNIC

${ }^{1}$ Research performed at Laboratory of Experimental Surgery, Faculty of Veterinary Medicine, University of Cuiaba (UNIC), Cuiaba-MT, Brazil. 
Tomographic imaging of fragmented cortical bone heteroimplant and methylmethacrylate in segmental bone defect of rabbit tibia 